\title{
Acute myocardial infarctation in patients with critical ischemia underwent lower limb revascularization
}

\author{
Infarto agudo do miocárdio em pacientes portadores de isquemia \\ crítica submetidos a revascularização de membros inferiores
}

Esdras Marques Lins'ㄱ, José Wellington Barros², Fernanda Appolônio², Eduardo Anacleto², Eduardo Cavalcanti Lima²

\begin{abstract}
Background: Atherosclerosis is the main cause of peripheral artery occlusive disease (PAOD) of the lower limbs. Patients with PAOD often also have obstructive atherosclerosis in other arterial sites, mainly the coronary arteries. This means that patients who undergo infrainguinal bypass to treat critical ischemia have a higher risk of AMI. There are, however, few reports in the literature that have assessed this risk properly. Objective: The aim of this study was to determine the incidence of acute myocardial infarction in patients who underwent infrainguinal bypass to treat critical ischemia of the lower limbs caused by PAOD. Material and Methods: A total of 64 patients who underwent 82 infrainguinal bypass operations, from February 2011 to July 2012 were studied. All patients had electrocardiograms and troponin I blood assays during the postoperative period (within 72 hours). Results: There were abnormal ECG findings and elevated blood troponin I levels suggestive of AMI in five (6\%) of the 82 operations performed. All five had conventional surgery. The incidence of AMI as a proportion of the 52 conventional surgery cases was $9.6 \%$. Two patients died. Conclusion: There was a $6 \% \mathrm{AMI}$ incidence among patients who underwent infrainguinal bypass due to PAOD. Considering only cases operated using conventional surgery, the incidence of AMI was $9.6 \%$.
\end{abstract}

Keywords: peripheral arterial disease; myocardial infarction; postoperative period.

\begin{abstract}
Resumo
Contexto: A doença arterial obstrutiva periférica (DAOP) afeta os membros inferiores (MMII) e tem como principal causa a aterosclerose. Por se tratar de uma doença sistêmica, é frequente que a aterosclerose cause o envolvimento simultâneo de outros sítios arteriais, especialmente das artérias coronárias. Desta forma, os pacientes submetidos a cirurgia de reconstrução arterial periférica, devido a isquemia crítica dos MMII, apresentam maior chance de infarto agudo do miocárdico (IAM). Apesar disso, há na literatura poucos relatos que avaliem a prevalência do IAM adequadamente neste grupo de pacientes. Objetivo: Avaliar incidência do infarto agudo do miocárdio no pósoperatório imediato de pacientes submetidos à revascularização de MMII devido a DAOP. Material e Métodos: Foram avaliados 64 pacientes portadores de DAOP submetidos a 82 cirurgias de revascularização arterial dos MMII, no período de fevereiro de 2011 a julho de 2012. Os pacientes foram submetidos no pós-operatório imediato (até 72 horas) a eletrocardiograma (ECG) e dosagem sanguínea de troponina I cardíaca. Resultados: Considerando as 82 cirurgias realizadas, em cinco (6\%) casos, foram encontradas alterações no ECG e elevação sanguínea da troponina I cardíaca compatíveis com infarto agudo do miocárdio. Considerando apenas as 52 cirurgias feitas por técnica convencional, a incidência de IAM foi de 9,6\%. Dois pacientes evoluíram ao óbito. Conclusão: No presente estudo, a incidência do infarto agudo do miocárdio nos pacientes submetidos à revascularização arterial de membros inferiores por DAOP foi de 6\%. Considerando apenas as cirurgias feitas por técnica convencional, a incidência de IAM foi de 9,6\%.
\end{abstract}

Palavras-chave: doença arterial periférica; infarto do miocárdio; período pós-operatório.

\footnotetext{
'Universidade Federal de Pernambuco - UFPE, Department of Surgery, Recife, PE, Brazil. 2 Instituto Materno Infantil de Pernambuco - IMIP, Vascular Surgery Service, Recife, PE, Brazil. Financial support: None.

Conflicts of interest: No conflicts of interest declared concerning the publication of this article Submitted on: 05.06.13. Accepted on: 08.20.13.
} 


\section{INTRODUCTION}

There is a high prevalence of Coronary Artery Disease (CAD) among patients with Peripheral Arterial Occlusive Disease (PAOD) and in the majority of cases atherosclerosis is the cause of both conditions. These patients are considered high risk for surgery ${ }^{1-5}$.

All PAOD patients should undergo detailed preoperative cardiac assessment with the objective of identifying cases with concomitant myocardial ischemia. These assessments are particularly important for patients with critical ischemia of the lower extremities (MMII) and for candidates for lower extremity revascularization surgery, because surgical stress, involving elevated catecholamine production, leading to tachycardia, vasoconstriction and myocardial hypoxia, increases their risk of acute myocardial infarction (AMI) $)^{6-11}$ during the perioperative period.

Acute myocardial infarction is the principal cardiac complication and greatest cause of death during the perioperative period of lower extremity revascularization surgery, i.e. from 30 days before to 30 days after surgery, although the most common time of onset is within the first 72 postoperative hours ${ }^{12-16}$.

While the link between PAOD and CAD has been definitively demonstrated in the literature, few studies have clearly established the incidence of postoperative AMI among infrainguinal revascularization patients. In view of these considerations, the objective of this study was to evaluate the incidence of AMI among patients with critical ischemia who had undergone revascularization of the lower extremities ${ }^{15-19}$.

\section{MATERIALS AND METHODS}

A total of 64 patients who had undergone 82 infrainguinal revascularization procedures, whether by conventional open or endovascular techniques, were studied. All of the patients had critical ischemia of the lower extremities, 33 were male and 31 were female. The patients were recruited from the vascular surgery ward at the Instituto de Medicina Integral Prof. Fernando Figueira between February 2011 and November 2012.

Forty-three of the patients had just one procedure, while 18 underwent two revascularization operations. Patients who were revascularized twice were admitted on a separate occasion for the second procedure and had another preoperative cardiac assessment before it.

The study design is of the observational cross-sectional type (a case series). Sample size was calculated using hypothesis testing for a population proportion (assuming that $15 \%$ of arterial revascularization surgery patients will suffer AMI, based on published data, a hypothesized proportion of $6 \%$, test power of $85 \%$ and a $5 \%$ significance level). The study was approved with no restrictions by the Human Research Ethics Committee.

All patients were assessed for AMI during the immediate postoperative period (within 72 hours). Acute myocardial infarction was diagnosed by assaying cardiac troponin I in blood, by analyzing electrocardiograms (ECG) and by observing signs and symptoms of myocardial ischemia. Cardiac troponin I was tested by immunoassay and 12-lead ECG was used.

Patients were diagnosed with AMI if their blood troponin I was greater than or equal to $1.5 \mathrm{ng} /$ $\mathrm{mL}$ in combination with precordial pain (and/or hypotension) or with an ECG showing ST segment elevation on at least two consecutive leads, as recommended by the second edition of the Sociedade Brasileira de Cardiologia's perioperative assessment guidelines.

Preoperative cardiac assessment was conducted for all elective procedures. In addition to clinical examination, patients had a simple chest X-ray, ECG, echocardiogram and resting and stressed myocardial perfusion scintigraphy. Patients whose scintigraphy results suggested myocardial ischemia were referred for coronary cineangiography to assess whether myocardial revascularization was needed prior to revascularization of the lower limb. For elective surgery patients, antiplatelet treatment with acetylsalicylic acid at $100 \mathrm{mg} /$ day was started 15 days before surgery and continued during the postoperative period, while patients who had emergency surgery and were not already on the drug were only prescribed it after surgery.

\section{RESULTS}

A total of 64 patients were studied, with a minimum age of 31 and a maximum age of 98 (mean of 64.3 years).

Clinical manifestations of PAOD were as follows: $61(95.3 \%)$ patients had minor tissue loss (Rutherford stage 4 ), while $3(4.7 \%)$ had rest pain (Rutherford stage 3).

Risk factors detected were as follows: 57 (89\%) patients had systemic arterial hypertension (HAS); $42(73.4 \%)$ were diabetic; $32(50 \%)$ had a history of smoking; and 11 (17.2\%) had chronic renal failure (IRC), Figure 1. 
Fifty-nine patients underwent preoperative cardiac assessment for a total of $77(94 \%)$ procedures, while $5(6 \%)$ patients were admitted for emergency surgery, meaning preoperative cardiac assessment was not possible. After the initial preoperative assessment, 11 (17\%) patients were referred for coronary cineangiography and $4(6 \%)$ were then subjected to revascularization of the myocardium before proceeding to infrainguinal revascularization.

Fifty-two $(63.4 \%)$ of the 82 infrainguinal revascularizations were conducted using conventional open surgery and $30(36.6 \%)$ were conducted using endovascular techniques (Figure 2).

There were $5(6 \%)$ cases of AMI during the postoperative periods of the 82 inguinal revascularization operations performed. Four $(80 \%)$ of the 5 patients who suffered AMI had had preoperative cardiac assessments, whereas $1(20 \%)$ of them was operated as an emergency case and so did not. None of the AMI cases were in patients who had undergone coronary cineangiography and myocardial revascularization prior to infrainguinal revascularization.

The mean age of patients who suffered AMI during the postoperative period was 63.6 years and median age was 68 . Table 1 lists the characteristics of patients who suffered AMI during the postoperative period.

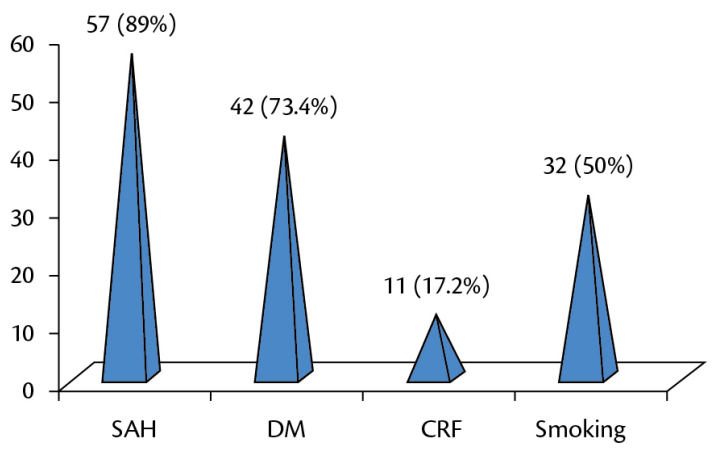

Figure 1. Risk factors by percentage of sample.
All of the AMI cases were in patients whose revascularization was performed using conventional surgical techniques. Indeed, if endovascular operations are excluded, the rate of AMI in the subset of open surgery patients is $9.6 \%$.

All of the AMI patients had high Troponin I levels and abnormal ECG findings (elevated ST segment) and 2 of them also exhibited hypotension.

\section{DISCUSSION}

Several different studies have established that there is a relationship between cardiac complications and a range of different types of arterial reconstruction surgery, but the association between AMI and infrainguinal revascularization surgery in patients with critical ischemia of lower extremities has rarely been described as in the present study. In contrast, the risk of AMI related to aortic surgery to treat aneurysms, for example, has been described at length ${ }^{20-26}$.

The risk of AMI linked to other types of arterial reconstruction, other than aortic surgery, was described by Flu et al. ${ }^{24}$ in a 2010 review of 13 articles published from 2000 to 2009 assessing AMI risk in connection with several different types of arterial reconstruction, including surgery to the

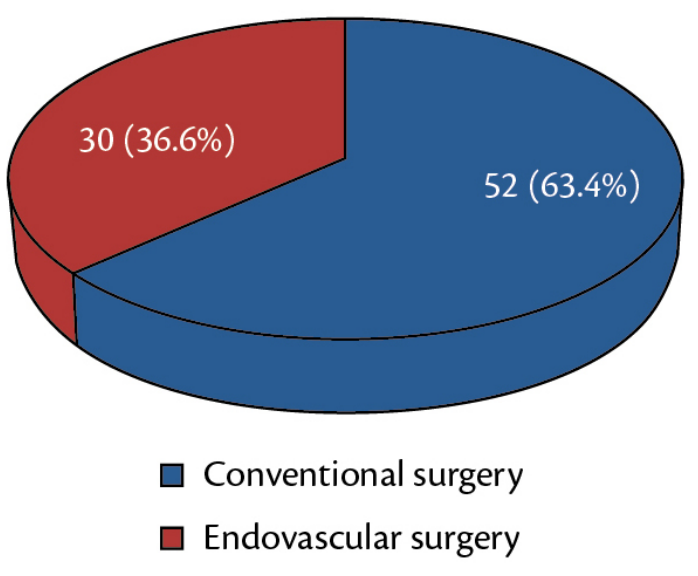

Figure 2. Proportions of conventional and endovascular surgery.

Table 1. Patients who suffered AMI during the postoperative period.

\begin{tabular}{|c|c|c|c|c|c|c|c|}
\hline Patient & Sex & Age & SAH & DM & Smoking & CRF & Death \\
\hline 1 & $\mathrm{~F}$ & 68 & - & & • & & • \\
\hline 2 & $\mathrm{~F}$ & 79 & • & • & & • & \\
\hline 3 & $M$ & 69 & - & & • & & \\
\hline 4 & $M$ & 48 & - & • & & • & • \\
\hline 5 & $\mathrm{~F}$ & 54 & - & - & & & \\
\hline
\end{tabular}


aorta and carotid arteries and also infrainguinal revascularizations of lower extremities, as studied here. The overall incidence of AMI varied from 1 to $26 \%$, but there was no data on the risk of AMI related specifically to infrainguinal revascularizations.

Similarly, in 2001 Landesberg et al. ${ }^{25}$ reported AMI incidence in 185 patients after a range of different arterial reconstruction procedures, including 73 cases of infrainguinal revascularization. In that study, $12(6.5 \%)$ patients had postoperative AMI, but no AMI incidence was reported for the specific subset of patients who underwent infrainguinal revascularization.

In 2003, Landesberg et al. ${ }^{26}$ conducted a prospective study of 447 patients who underwent revascularization of varying arterial sites, such as the aorta and the carotid and infrainguinal arteries, reporting that $23.9 \%$ of the patients had postoperative AMI, but this study also failed to report an AMI rate specific to infrainguinal revascularization patients.

The lower AMI incidence (6\%) observed in this study, compared with reports in the literature, may be explainable by the fact that the majority of studies included patients who had had surgery for reconstruction of the aorta, since these cases involve greater hemodynamic stress, caused by factors such as clamping the aorta, greater blood loss and longer duration anesthesia, which increases the risk of AMI. Additionally, patients whose revascularization was conducted using endovascular techniques did not suffer AMI, which may be because these methods reduce hemodynamic stress further still ${ }^{20-26}$.

Additionally, the patients in this study were put on anti-platelet drugs from the preoperative period onwards, which has been described as a protective factor against AMI. The role of acetylsalicylic acid in preventing death, acute myocardial infarction and cerebral vascular accidents in patients at high risk of occlusive cardiovascular events was fully demonstrated by the Antithrombotic Trialists Collaboration (ATC) in 2002, when 287 studies involving 135,000 patients comparing antiplatelet treatment with placebo were analyzed ${ }^{1,27}$.

The low AIM incidence observed in this study may also owe something to the rigorous preoperative cardiac assessment that made it possible to identify patients in need of coronary revascularization prior to revascularization of the lower extremities, even though this assessment could not be performed in five cases because surgery was in response to an emergency.

The indications for coronary revascularization used here are based on the recommendations contained in the second edition of the Sociedade Brasileira de Cardiologia's perioperative assessment guidelines which demand myocardial scintigraphy when ergometric tests are ruled out by physical limitations, which is the case with the majority of patients with critical ischemia of the lower extremities. In this study, patients were sent for coronary cineangiography if they had scintigraphy findings indicating ischemia ${ }^{2}$.

\section{CONCLUSIONS}

The incidence of acute myocardial infarction among patients who underwent arterial revascularization of the lower extremities because of Peripheral Arterial Occlusive Disease was 6\%, but if patients whose revascularization was conducted using conventional surgery are analyzed separately, the incidence of AMI rises to $9.6 \%$.

\section{REFERENCES}

1. Norgren L, Hiatt WR, Dormandy JA, Nehler KAH, Fowkes FGR on behalf of the TASC II working Group. Inter-Society Consensus for the management of peripheral Arterial Disease (TASC II). J VasC Bras. 2007;6(Supl 2):S193-259.

2. Iran castro, coordenador. II Diretriz de Avaliação Perioperatória da Sociedade Brasileira de Cardiologia. Arq Bras Cardiol. 2011;96(3 supl.1):1-68.

3. Lastoria S, Maffei FHA. Aterosclerose Obliterante Periférica: Epidemiologia, Fisiopatologia, Quadro Clínico e Diagnóstico. In: Maffei FHA, Lastoria S, Yoshida WB, Rolol HA, Gianini M, Moura R. Doenças Vasculares Periféricas. 4. ed. Rio de Janeiro: GuanabaraKoogan; 2008. p. 1141-55.

4. Mello AV, Dos Santos CMT, Oliveira BC, Mello RV. Revascularização distal dos membros inferiores: experiência de 13 anos J Vasc Bras. 2002;1:181-92.

5. Mourad JJ, Cacoub P, Collet JP, et al. Screening of unrecognized peripheral arterial disease (PAD) using ankle-brachial index in high cardiovascular risk patients free from symptomatic PAD. J Vasc Surg. 2009;50:572-80. PMid:19560312. http://dx.doi.org/10.1016/j. jvs.2009.04.055

6. Kim LJ, Martinez EA, Faraday N, et al. Cardiac troponin-I predicts short-term mortality in vascular surgery patients. Circulation. 2002;106:2366-71. PMid:12403668. http://dx.doi.org/10.1161/01. CIR.0000036016.52396.BB

7. Kertai JH, Boersma E, Bax JJ, et al. A meta-analysis comparing the prognostic accuracy of six diagnostic tests for predicting perioperative cardiac risk in patients undergoing major vascular surgery. Heart. 2003 Nov;89(11):1327-34. PMid:14594892 PMCid:PMC1767930. http://dx.doi.org/10.1136/heart.89.11.1327

8. Scrutinio D, Passantino A, Di Serio F, Angilleta D, Santoro D, Regina G. High-sensitivity C-reactive protein predicts cardiovascular events and myocardial damage after vascular surgery. J Vasc Surg. 2011;54:474-9. PMid:21458205. http://dx.doi.org/10.1016/j. jvs.2011.01.041

9. Frankini AD, Pezzella MVC. Revascularização no pé em paciente com isquemia crítica. J Vasc Br. 2002;1(3):193-200.

10. Boersma E, Kertai MD, Schouten O, et al. Perioperative cardiovascular mortality in noncardiac surgery: validation of 
the Lee cardiac risk index. Am J Med. 2005; 118(10):1134-41. PMid:16194645. http://dx.doi.org/10.1016/j.amjmed.2005.01.064

11. Landesberg G, Mosseri M, Shatz V, et al. Cardiac Troponin After Major Vascular Surgery. JACC. 2004;44:569-75. PMid:15358022. http://dx.doi.org/10.1016/j.jacc.2004.03.073

12. Raby KE, Barry J, Creager MA, Cook EF, Weisberg MC, Goldman L. Detection and significance of intraoperative and postoperative myocardial ischemia in peripheral vascular surgery. JAMA. 1992;268(2):222-7. PMid:1608141. http://dx.doi.org/10.1001/ jama.1992.03490020070033

13. Bolliger D, Seeberger MD, Lurati Buse GA, et al. A preliminary report on the prognostic significance of preoperative brain natriuretic peptide and postoperative cardiac troponin in patients undergoing major vascular surgery. Anesth Analg. 2009;108(4):1069-75. PMid:19299763. http://dx.doi.org/10.1213/ ane.0b013e318194f3e6

14. Back MR, Leo F, Cuthbertson D, Johnson BL, Shamesmd ML, Bandyk DF. Long-term survival after vascular surgery: specific influence of cardiac factors and implications for preoperative evaluation. J Vasc Surg. 2004 Oct;40(4):752-60. PMid:15472605. http://dx.doi.org/10.1016/j.jvs.2004.07.038

15. Williams FM, Bergin JD. Cardiac screening before noncardiac surgery. Surg Clin North Am. 2009 Aug;89(4):747-62. PMid:19782835. http://dx.doi.org/10.1016/j.suc.2009.05.001

16. Waggoner AD, Sicard GA, Geltman EM, Schechtman KB, PérezJE. Dobutamine stress echocardiography predicts surgical outcome in patients with an aortic aneurysm and peripheral vascular disease. J Am Coll Cardiol. 1993 Mar 15;21(4):957-63. http:// dx.doi.org/10.1016/0735-1097(93)90353-3

17. Poldermans D, Bax JJ, Boersma E, et al. Guidelines for preoperative cardiac risk assessment and perioperative cardiac management in non-cardiac surgery. Eur Heart J. 2009;30:2769812. PMid:19713421. http://dx.doi.org/10.1093/eurheartj/ehp337

18. Thygesen K, Alpert SJ, Jaffe SA, et al. Third Universal Definition of Myocardial Infarction. JACC. 2012;60.

19. Monaco M, Stassano P, Di Tommaso L, et al. Systematic strategy of prophylactic coronary angiography improves long-term outcome after major vascular surgery in medium- to high-risk patients: a prospective, randomized study. J Am Coll Cardiol. 2009 Sep 8;54(11):989-96. PMid:19729114. http://dx.doi.org/10.1016/j. jacc.2009.05.041

20. Andrews N, Jenkins J, Andrews G, Walker P. Using postoperative cardiac Troponin-I (cTi) levels to detect myocardial ischaemia in patients undergoing vascular surgery. Cardiovasc Surg. 2001;9(3):254-65. http://dx.doi.org/10.1016/ S0967-2109(00)00139-3

21. Haggart PC, Adam DJ, Ludman PF, Bradbury AW. Comparison of cardiac troponin I and creatine kinase ratios in the detection of myocardial injury after aortic surgery. $\mathrm{Br}$ J Surg. 2001;88(9):1196-200. PMid:11531867. http://dx.doi. org/10.1046/j.0007-1323.2001.01854.x

22. Barbagallo M, Casati A, Spadini E, et al. Early increases in cardiac troponin levels after major vascular surgery is associated with an increased frequency of delayed cardiac complications. J Clin Anesth. 2006;18(4):280-5. PMid:16797430. http://dx.doi. org/10.1016/j.jclinane.2005.11.005
23. McFalls EO, Ward HB, Moritz TE, et al. Predictors and outcomes of a perioperative myocardial infarc- tion following elective vascular surgery in patients with docu- mented coronary artery disease: results of the CARP trial. Eur Heart J. 2008; 29(3):394-401. PMid:18245121. http://dx.doi.org/10.1093/eurheartj/ehm620

24. Flu JW, Schouten O, Van Kuijk PJ, Poldermans D. Perioperative Cardiac Damage in Vascular Surgery Patients. Eur J Vasc Endovasc Surg. 2010;40:1-8. PMid:20400340. http://dx.doi.org/10.1016/j. ejvs.2010.03.014

25. Landesberg G, Mosseri M, Zahger D, et al. Myocardial Infarction After Vascular Surgery: The Role of Prolonged, Stress-Induced, ST Depression-Type Ischemia. JACC. 2001;37:1839-45. http://dx.doi. org/10.1016/S0735-1097(01)01265-7

26. Landesberg G, Shatz V, Akopnik I, et al. Association of Cardiac Troponin, CK-MB, and Postoperative Myocardial Ischemia With Long-Term Survival After Major Vascular Surgery. JACC. 2003;42:1547-54. PMid:14607436. http://dx.doi.org/10.1016/j. jacc.2003.05.001

27. ATC. Collaborative meta-analysis of randomized trials of antiplatelet therapy for prevention of death, myocardial infarction, and stroke in high risk patients. BMJ. 2002;324:71-86. http://dx.doi.org/10.1136/bmj.324.7329.71

Correspondence

Esdras Marques Lins

Rua Dom Bosco, 632, Ed. Rita de Cássia, apto 1202, Boa Vista CEP 50070-070 - Recife (PE), Brazil

Fone: (81) 9615-4155

E-mail:esdraslins@uol.com.br

Author's information

EML is PhD, Adjunct professor of Vascular Surgery at Universidade Federal de Pernambuco (UFPE), Department of Surgery, Center for Health Sciences (CCS), Recife, PE, Brazil.

JWB and FA are Vascular surgeon with a Lato sensu degree from Sociedade Brasileira de Angiologia e de Cirurgia Vascular (SBACV), Instituto Materno Infantil de Pernambuco (IMIP), Vascular Surgery Service, Recife, PE, Brazil.

EA is Resident physician in Vascular Surgery, Instituto Materno Infantil de Pernambuco (IMIP), Vascular Surgery Service, Recife, PE, Brazil. ECL is Vascular surgeon, Instituto Materno Infantil de Pernambuco (IMIP), Vascular Surgery Service, Recife, PE, Brazil.

Author's contributions Conception and design: JWB Analysis and interpretation: EML

Data collection: ECL, EA

Writing the article: EML, FA Critical revision of the article: FA Final approval of the article*: JWB Statistical analysis: N/A

Overall responsibility: JWB Obtained funding: None.

*All authors have read and approved of the final version of the article submitted to I Vasc Bras. 